\author{
Rasa Pauliukaite - Monica Florescu \\ Christopher M. A. Brett
}

\title{
Characterization of cobalt- and copper hexacyanoferrate-modified carbon film electrodes for redox-mediated biosensors
}

\begin{abstract}
Cobalt and copper hexacyanoferrate films (CoHCF and $\mathrm{CuHCF}$ ) were formed at carbon film electrodes by three different one-step processes: cycling the applied potential, application of a constant current, and chemically. All hexacyanoferrate films obtained were characterized electrochemically by cyclic voltammetry and electrochemical impedance spectroscopy. To evaluate their possible use as redox mediators for biosensors, they were applied to the determination of hydrogen peroxide in neutral phosphate buffer saline electrolyte. Chemically deposited $\mathrm{CuHCF}$ was found to be generally the most suitable as a mediator, although CoHCF made by potential cycling is the most useful when a very low detection limit is necessary.
\end{abstract}

Keywords Cobalt hexacyanoferrate $\cdot$ Copper hexacyanoferrate Carbon film electrode . Electrochemical impedance spectroscopy $\cdot$ Hydrogen peroxide determination

\section{Introduction}

Transition metal cyanide complexes have been attractive subjects of study for several centuries in different fields of chemistry and physics [1]. The first transition metal

Dedicated to Professor George Horanyi on the occasion of his 70th birthday, in recognition of his outstanding contributions to electrochemistry.

R. Pauliukaite · C. M. A. Brett ( $\square)$

Departamento de Quimica, Universidade de Coimbra, 3004-535 Coimbra, Portugal

E-mail: brett@ci.uc.pt

Tel: + 351-239-835295

Fax: + 351-239-835295

M. Florescu

Department of Physics,

Transilvania University of Brasov,

2200 Brasov, Romania cyanide coordination compound obtained was iron(III) hexacyanoferrate(II) or Prussian Blue (PB), which has had broad applications up until now, owing to its favourable properties as a pigment [1-3]. Recently, various other transition metal hexacyanoferrates have been synthesized chemically and electrochemically and characterized by spectroscopic and electrochemical methods, such as those of nickel, copper, cobalt, and indium, (for example, by Kulesza et al. [4-10] and Cataldi et al. [11-15]), including the properties of hybrid hexacyanoferrates such as nickel-palladium [9] and ruthenium-cobalt [15].

A number of transition metal hexacyanoferrates are becoming widely used redox mediators for biosensors [1-2]. The possibility for selective detection of $\mathrm{H}_{2} \mathrm{O}_{2}$, produced by enzymatic glucose reaction with glucose oxidase, by its reduction on PB-modified electrodes was first demonstrated by Karyakin et al. [16], and later has been used for the development of sensors and biosensors due to its ability to decrease the kinetic barrier for reduction or oxidation of hydrogen peroxide [17-20]. Besides PB, other metal hexacyanoferrates investigated for hydrogen peroxide detection and in oxidase-based biosensors are $\mathrm{CuHCF}$ [21-23], cobalt hexacyanoferrate (CoHCF) [24-27], and nickel hexacyanoferrate (NiHCF) [28-30]. An important possible advantage is their increased stability over a wider $\mathrm{pH}$ range, particularly in alkaline solution. Electrocatalytic reactions of other species besides hydrogen peroxide have also been demonstrated on hexacyanoferrate films, for example of neurotransmitters [31] or thiosulphate at CoHCF films [32] and ascorbic acid at CuHCF films [33].

In this work, $\mathrm{CoHCF}$ and $\mathrm{CuHCF}$ films have been formed on carbon film electrodes. These carbon film electrodes, made from carbon film electrical resistors [34], have been shown to have a wide potential window, particularly after electrochemical conditioning, and possess advantageous properties for various applications such as trace metal electroanalytical sensors [35] and as substrates for oxidase-based biosen- 
sors $[26,36]$. They have recently been characterized by electrochemical impedance spectroscopy in various electrolytes over a wide $\mathrm{pH}$ range [37]. Hexacyanoferrate films are deposited on these carbon electrode substrates in three different ways: cycling of the electrode potential, galvanostatic and chemical deposition, electrochemical characterisation using cyclic voltammetry, and electrochemical impedance spectroscopy, and compared for the detection of hydrogen peroxide.

\section{Experimental}

\section{Reagents}

$\mathrm{CuCl}_{2} \cdot 2 \mathrm{H}_{2} \mathrm{O}, \mathrm{CoCl}_{2} \cdot 6 \mathrm{H}_{2} \mathrm{O}, \mathrm{K}_{3} \mathrm{Fe}(\mathrm{CN})_{6}$, and $\mathrm{KCl}$ were analytical grade and purchased from Merck (Germany). All solutions were prepared in Millipore Milli-Q nanopure water (resistivity $\geq 18 \mathrm{M} \Omega \mathrm{cm}$ ). Experiments were carried out at room temperature $\left(24 \pm 1^{\circ} \mathrm{C}\right)$.

\section{Electrode preparation}

The carbon film electrodes were made from carbon film electrical resistors (2 $\Omega$ resistance) $[34,35]$ of length $4 \mathrm{~mm}$ and diameter $1.5 \mathrm{~mm}$. One of the gold contact caps is removed and the other with external contact wire is covered with a plastic sheath and epoxy resin, leaving an exposed electrode area of $\sim 0.20 \mathrm{~cm}^{2}$ (Fig. 1). The films of $\mathrm{CoHCF}$ and $\mathrm{CuHCF}$ were deposited in three different ways:

- By potential cycling between $0.0 \mathrm{~V}$ and $+0.9 \mathrm{~V}$ for CoHCF [27] or between $+0.25 \mathrm{~V}$ and $+0.9 \mathrm{~V}$ for $\mathrm{CuHCF}$ for 25 cycles at a scan rate of $50 \mathrm{mV} \mathrm{s}^{-1}$;

- By application of a constant current $\left(-100 \mu \mathrm{A} \mathrm{cm}^{-2}\right)$ for $300 \mathrm{~s}$;

- By direct adsorption, immersing the carbon film electrode substrate in the deposition solution.

All solutions for $\mathrm{CoHCF}$ film formation contained $100 \mathrm{mM} \mathrm{KCl}$ to which was added $1 \mathrm{mM} \mathrm{CoCl}_{2}+$ $0.5 \mathrm{mM} \mathrm{K}{ }_{3} \mathrm{Fe}(\mathrm{CN})_{6}$ for deposition by potential cycling; $5 \mathrm{mM} \mathrm{CoCl}_{2}+2.5 \mathrm{mM} \mathrm{K}_{3} \mathrm{Fe}(\mathrm{CN})_{6}$ for galvanostatic

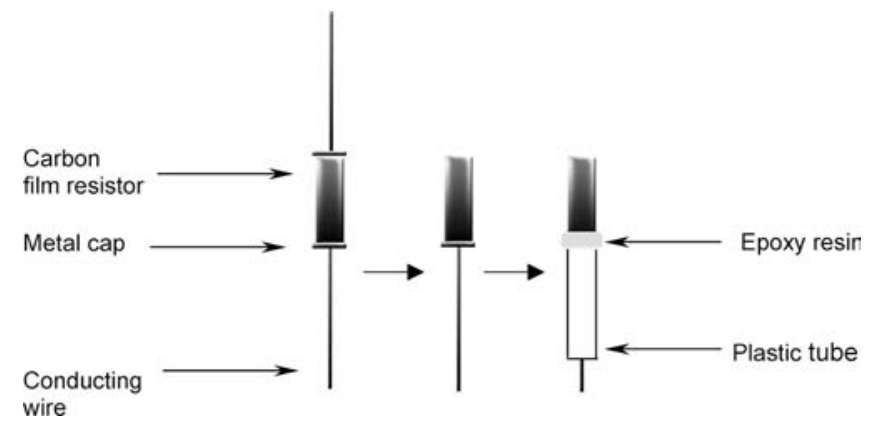

wire

Fig. 1 Scheme of carbon film resistor electrode preparation deposition, and $10 \mathrm{mM} \mathrm{CoCl}{ }_{2}+10 \mathrm{mM} \mathrm{K}_{3} \mathrm{Fe}(\mathrm{CN})_{6}$ for chemical deposition. For $\mathrm{CuHCF}$, the solution contained $10 \mathrm{mM} \mathrm{CuCl} 2,10 \mathrm{mM} \mathrm{K}{ }_{3} \mathrm{Fe}(\mathrm{CN})_{6}$, and $100 \mathrm{mM} \mathrm{KCl}$ for all three types of deposition.

After film formation, the electrodes were dried in a hot-air stream and left for $24 \mathrm{~h}$ in air to stabilize.

\section{Instrumentation}

Measurements were performed using a computer-controlled $\mu$-Autolab Type II potentiostat/galvanostat with GPES 4.9 software (Eco Chemie, Netherlands). The three-electrode electrochemical cell contained the Co$\mathrm{HCF}-$ or $\mathrm{CuHCF}$-coated carbon film working electrode, a platinum foil counter electrode and a saturated calomel electrode (SCE) as reference.

Electrochemical impedance measurements were carried out in the same electrochemical cell with a PCcontrolled Solartron 1250 frequency response analyser coupled to a Solartron 1286 electrochemical interface using ZPlot 2.4 software (Solartron Analytical, UK). A sinusoidal voltage perturbation of rms amplitude $10 \mathrm{mV}$ was applied, scanning from $65 \mathrm{kHz}$ to $0.1 \mathrm{~Hz}$ with ten points per frequency decade, integration time $120 \mathrm{~s}$. Fitting to equivalent circuits was performed with ZView 2.4 software.

\section{Results and discussion}

Deposition of CoHCF and CuHCF films

\section{Potential cycling}

The most common method for deposition of metal hexacyanoferrates is cycling the potential applied to the electrode in appropriate electrolyte solutions [1-3]. Figure 2a shows deposition of CoHCF and CuHCF by potential cycling; the film growth depends on the ratio of the precursor salts and the hexacyanoferrate salt employed. From the variation of oxidation peak current with cycle number, it can be seen that the $\mathrm{CoHCF}$ film grows at a fast, constant rate up to 20 cycles and then more slowly (Fig. 2a1). A very small redox couple at $+0.2 \mathrm{~V}$ disappeared completely after 15 cycles and the second at $+0.4 \mathrm{~V}\left(\mathrm{Co}^{\mathrm{II}} \leftrightarrow \mathrm{Co}^{\mathrm{III}}\right)$ increased rapidly in size. A similar film growth on wax-impregnated graphite was reported in [38], using a slightly different deposition solution $(0.5 \mathrm{M} \mathrm{KCl}$ rather than $0.1 \mathrm{M}$ $\mathrm{KCl})$.

Deposition of $\mathrm{CuHCF}$ by potential cycling shows a different behaviour to CoHCF. Fast growth occurred for only 5 cycles; the deposition rate then slowed down significantly and after 10 cycles, only insignificant changes occurred (Fig. 2a2). During CuHCF deposition, peaks corresponding to both redox couples, $\mathrm{Cu}^{\mathrm{I}} \leftrightarrow$ $\mathrm{Cu}^{\mathrm{II}}$ and $\mathrm{Fe}^{\mathrm{II}} \leftrightarrow \mathrm{Fe}^{\mathrm{III}}$, are clearly seen. 

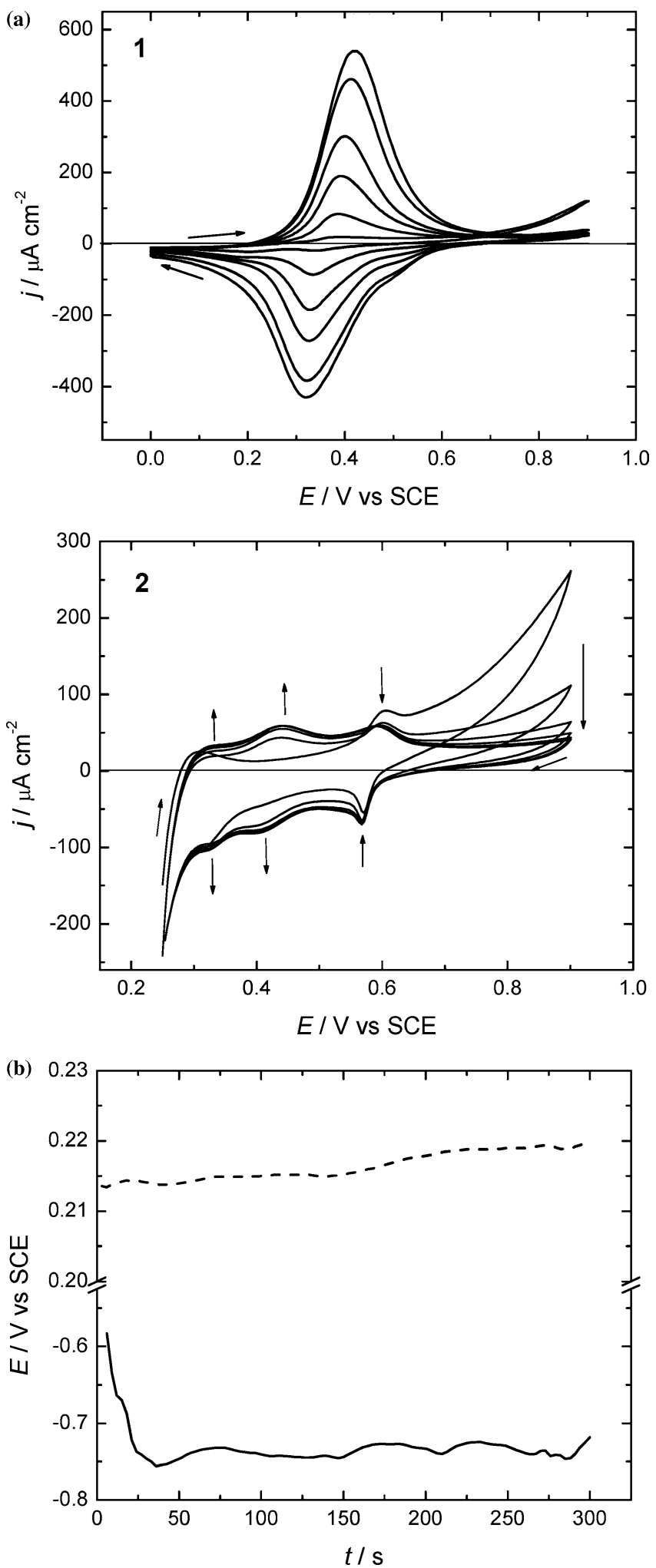

Fig. 2 a Cyclic voltammograms showing deposition of $1 \mathrm{CoHCF}$ and $2 \mathrm{CuHCF}$ by potential cycling - cycles $1,5,10,15,20$, and 25 . b Variation of potential with time during galvanostatic deposition of $(-) \mathrm{CoHCF}$ and $(---) \mathrm{CuHCF}$

\section{Galvanostatic deposition}

A slightly different film growth was obtained by galvanostatic deposition. In the case of $\mathrm{CoHCF}$, the potential decreased rapidly up to $30 \mathrm{~s}$, then remained constant (Fig. 2b, solid line). During galvanostatic deposition of $\mathrm{CuHCF}$, the potential slowly increased for the whole $300 \mathrm{~s}$ (Fig. 2b, dashed line). Although the same current $\left(-100 \mathrm{~mA} \mathrm{~cm}{ }^{-2}\right)$ was applied for both hexacyanoferrates, $\mathrm{CoHCF}$ and $\mathrm{CuHCF}$, the deposition potential differed substantially, i.e. it was $\sim+0.22 \mathrm{~V}$ versus SCE in the case of $\mathrm{CuHCF}$, where usually $\mathrm{Cu}^{2+}$ reduction takes place, and in the case of CoHCF, it was much more negative $(\sim-0.75 \mathrm{~V}$ versus SCE).

Two-step deposition methods have also been described. Usually a constant current is used in the first step to cause galvanostatic deposition of metal and then potential cycling is done in potassium hexacyanoferrate solution, e.g. [21]. It is also possible that here, during galvanostatic deposition from the metal hexacyanoferrate solution, the deposition occurs in two steps, i.e. first metal is deposited and then the fresh film reacts with $\left[\mathrm{Fe}(\mathrm{CN})_{6}\right]^{3-}$. Nevertheless, there is no direct evidence of this.

\section{Chemical immersion}

Films were also deposited chemically by immersion of the carbon film electrodes in the deposition solution (details in Experimental section). A two-step chemical deposition has also been reported in this case, where metal was deposited by electroless plating and after this the electrode was immersed for a very short time in $\mathrm{K}_{3} \mathrm{Fe}(\mathrm{CN})_{6}$ solution [26].

Electrochemical characterisation of cobalt and copper hexacyanoferrates

\section{Cyclic voltammetry}

In general, films obtained by different methods have different structure and thickness [1]. On carbon film substrates, this is clearly seen in Fig. 3, which shows the electrochemical behaviour of the films in $0.1 \mathrm{M} \mathrm{KCl}$ solution after aging for one day at room temperature in air. The thickest films of both hexacyanoferrates were obtained by chemical deposition; chemical deposition is usually done for a longer time than the electrochemical procedures. Electrochemically deposited films also differ depending on whether potential cycling or application of a constant current is used: those obtained by potential cycling exhibited CVs quite different from those obtained galvanostatically, which were more similar to chemically deposited metal hexacyanoferrates. The charge under the cyclic voltammogram anodic peaks is $\sim 50 \mu \mathrm{C} \mathrm{cm}^{-2}$ for chemical deposition and galvanostatically formed films, and $\sim 5 \mu \mathrm{C} \mathrm{cm}^{-2}$ for films formed by potential cycling for other $\mathrm{CoHCF}$ and $\mathrm{CuHCF}$ films. 
(a)
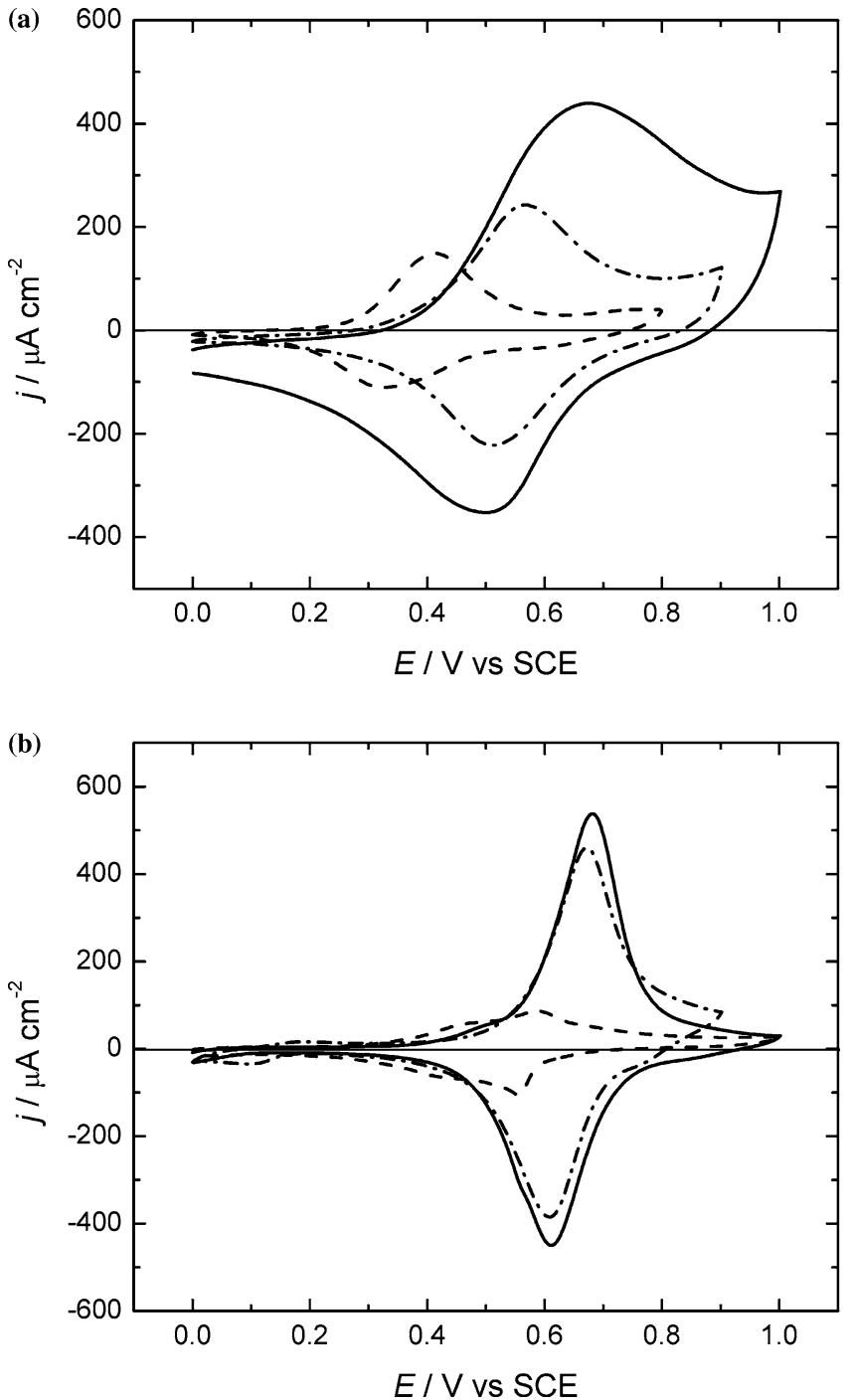

Fig. 3 Cyclic voltammograms in $0.1 \mathrm{M} \mathrm{KCl}$ of (a) $\mathrm{CoHCF}$ and (b) $\mathrm{CuHCF}$ films obtained by $(---)$ potential cycling, $(-\cdot-\cdot-)$ galvanostatically, and (- chemically after 1 day of stabilization in air at room temperature. Potential sweep rate $50 \mathrm{mV} \mathrm{s} \mathrm{s}^{-1}$

The CoHCF deposited chemically exhibits one redox couple with a quite large peak separation (Fig. 3a). This couple can probably be attributed to the summation of both processes $\mathrm{Co}^{\mathrm{II}} \leftrightarrow \mathrm{Co}^{\mathrm{III}}$ and $\mathrm{Fe}^{\mathrm{II}} \leftrightarrow \mathrm{Fe}^{\mathrm{III}}$. The redox couple is irreversible with a peak separation of $0.149 \mathrm{~V}$ for a chemically deposited CoHCF film. The reversible redox peaks on the galvanostatically deposited film are much smaller than on the chemically deposited film, with a peak separation of $0.05 \mathrm{~V}$. Films deposited by potential cycling show two redox couples. The first of these, at less positive potentials than on chemically or galvanostatically prepared films, i.e. $+0.3 \mathrm{~V}$ to $+0.4 \mathrm{~V}$, is due to $\mathrm{Co}^{\mathrm{II}} \leftrightarrow \mathrm{Co}^{\mathrm{III}}$, and the second (a small peak) at $+0.6 \mathrm{~V}$ to $+0.7 \mathrm{~V}$ versus SCE can be attributed to iron in the hexacyanoferrate ion $[3,39]$. Thus, the structure of the CoHCF films changes according to the deposition method. A detailed study of CoHCF films deposited by potential cycling was done in a previous work [27].
A similar tendency was found with CuHCF films, except that the peaks are better defined than at $\mathrm{CoHCF}$ and the peak separation is smaller (Fig. 3b). The redox couple of the hexacyanoferrate anion is clearly seen at $\sim+0.6 \mathrm{~V}$, and also $\mathrm{Cu}^{\mathrm{I}} \leftrightarrow \mathrm{Cu}^{\mathrm{II}}$ at $+0.1-+0.15 \mathrm{~V}$ versus SCE [40] is visible at the galvanostatically deposited film, while at chemically deposited $\mathrm{CuHCF}$, the first couple is suppressed and hardly evident. In the case of deposition by potential cycling, the peaks are closer to each other: the $\mathrm{Cu}^{\mathrm{I} / \mathrm{II}}$ redox peaks are more positive $(\sim+0.45 \mathrm{~V})$ and $\mathrm{Fe}^{\mathrm{II} / \mathrm{III}}$ peaks $(\sim+0.57 \mathrm{~V})$ are less positive than at galvanostatically deposited $\mathrm{CuHCF}$ films.

Figure 4 presents the analysis of CoHCF films in $0.1 \mathrm{M} \mathrm{KCl}$ by cyclic voltammetry at different potential sweep rates, $v$. Figure $4 \mathrm{a}$ shows CVs at CoHCF deposited chemically. At low sweep rates, $5 \mathrm{mV} \mathrm{s}^{-1}$ and $10 \mathrm{mV} \mathrm{s}^{-1}$, double redox peaks are seen - oxidation at $+0.6 \mathrm{~V}$ to $+0.7 \mathrm{~V}$ and reduction at $+0.5 \mathrm{~V}$ to $+6 \mathrm{~V}$ versus SCE - which transform to one broad peak at faster sweep rates. The peak current shows a linear dependence on $v^{1 / 2}$ with slope $\sim \pm 0.045$ $\mathrm{mA} \mathrm{cm}{ }^{-2} \mathrm{mV}^{-1 / 2} \mathrm{~s}^{1 / 2}$ (Fig. 4b, squares, Table 1), and $j_{\mathrm{p}, \mathrm{a}} / j_{\mathrm{p}, \mathrm{c}}$ is nearly 1 so that the electrochemical process at this film is close to being diffusion controlled. However, the peak position changes with increasing scan rate and peak separation increases. The dependence of the peak potential on $\lg v$ is linear with slope 0.085 for oxidation and $-0.093 \mathrm{~V} /$ decade for reduction (Fig. $4 \mathrm{~b}$, squares).

These results suggest that the rate-determining step of the process could be diffusion of the cation of the supporting electrolyte for charge compensation during the electrochemical redox reaction of hexacyanoferrate(II/ III) [39], such as given in the following scheme [25]:

$$
\begin{aligned}
& \mathrm{Co}_{3}^{\mathrm{III}}\left[\mathrm{Fe}^{\mathrm{III}}(\mathrm{CN})_{6}+2 \mathrm{e}^{-}+\mathrm{K}^{+} \rightleftarrows \mathrm{K}_{2} \mathrm{Co}^{\mathrm{II}} \mathrm{Fe}^{\mathrm{II}}(\mathrm{CN})_{6}\right. \\
& \mathrm{K}_{2} \mathrm{Co}^{\mathrm{II}} \mathrm{Fe}^{\mathrm{II}}(\mathrm{CN})_{6} \rightleftarrows \mathrm{KCo}^{\mathrm{III}} \mathrm{Fe}^{\mathrm{II}}(\mathrm{CN})_{6}+\mathrm{e}^{-}+\mathrm{K}^{+} \\
& \mathrm{KCo}^{\mathrm{III}} \mathrm{Fe}^{\mathrm{II}}(\mathrm{CN})_{6} \rightleftarrows \mathrm{Co}^{\mathrm{III}} \mathrm{Fe}^{\mathrm{III}}(\mathrm{CN})_{6}+\mathrm{e}^{-}+\mathrm{K}^{+}
\end{aligned}
$$

A similar peak dependence was found at $\mathrm{CoHCF}$ deposited by potential cycling, except in this case, the slope of the linear peak current dependence on $v^{1 / 2}$, $\sim 0.004 \mathrm{~mA} \mathrm{~cm}^{-2} \mathrm{mV}^{-1 / 2} \mathrm{~s}^{1 / 2}$ and $\sim-0.008 \mathrm{~mA} \mathrm{~cm}^{-2}$ $\mathrm{mV}^{-1 / 2} \mathrm{~s}^{1 / 2}$ (Fig. 4b, diamonds), for oxidation and reduction respectively, was much smaller than at the same film deposited by chemical immersion. These data are different from those obtained in [27] due to different experimental conditions. The peak potential dependence on $\lg v$ was similar to chemical CoHCF film with a slope of $\sim \pm 0.12 \mathrm{~V}$ per decade.

A linear peak current dependence on square root of sweep rate was also found at galvanostatically deposited CoHCF films (Fig. 4b, circles); the slopes were $0.059 \mathrm{~mA} \mathrm{~cm}^{-2} \mathrm{mV}^{-1 / 2} \mathrm{~s}^{1 / 2}$ and $-0.07 \mathrm{~mA} \mathrm{~cm}^{-2}$ $\mathrm{mV}^{-1 / 2} \mathrm{~s}^{1 / 2}$. The change in peak position with scan rate is similar to that at chemically deposited $\mathrm{CoHCF}$, with a linear dependence on $\lg v$ for both oxidation and reduction peaks. The slope of the oxidation plot is two 

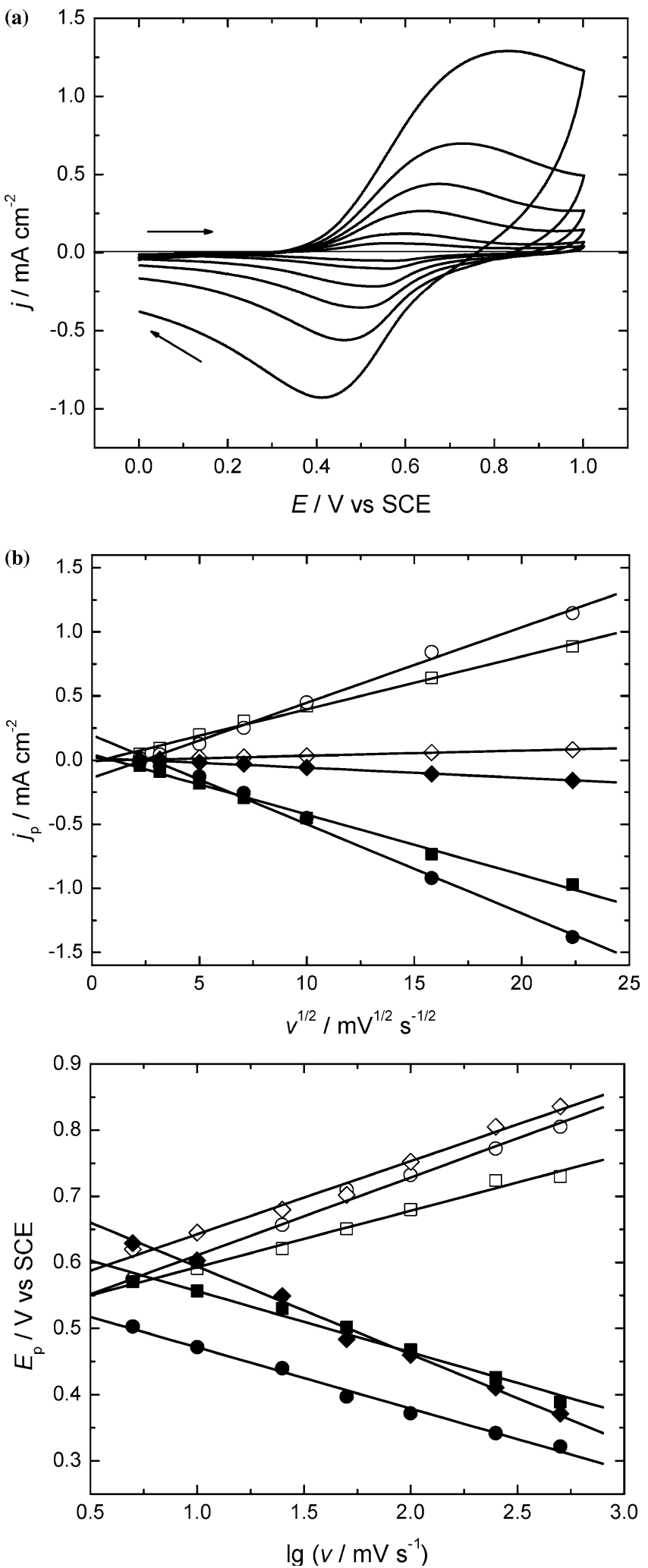

times higher than that of reduction $\left(0.118 \mathrm{~V} / \mathrm{lg} \mathrm{mV} \mathrm{s} \mathrm{m}^{-1}\right.$ and $-0.060 \mathrm{~V} / \mathrm{lg} \mathrm{mV} \mathrm{s}^{-1}$ respectively).

A similar variation in electrochemical behaviour was also found in $\mathrm{CuHCF}$ films deposited in various ways
Fig. 4 Analysis of CoHCF films by cyclic voltammetry in $0.1 \mathrm{M}$ $\mathrm{KCl}$. a Cyclic voltammograms of $\mathrm{CoHCF}$, deposited chemically, at sweep rates, $v: 5 \mathrm{mV} \mathrm{s} \mathrm{s}^{-1}, 10 \mathrm{mV} \mathrm{s} \mathrm{s}^{-1}, 25 \mathrm{mV} \mathrm{s} \mathrm{s}^{-1}, 50 \mathrm{mV} \mathrm{s} \mathrm{s}^{-1}$, $100 \mathrm{mV} \mathrm{s}^{-1}, 250 \mathrm{mV} \mathrm{s}{ }^{-1}$, and $500 \mathrm{mV} \mathrm{s}{ }^{-1}$. b Analysis of cyclic voltammograms of $\mathrm{CoHCF}$ deposited chemically (open square, filled square), galvanosta-tically (open circle, filled circle), and by potential cycling (open diamond, filled diamond): dependence of peak current, $I_{\mathrm{p}}$, on $v^{1 / 2}$ and peak potential, $E_{\mathrm{p}}$, on $\lg v$

(Fig. 5). Figure 5a shows CVs at chemically deposited $\mathrm{CuHCF}$ at different scan rates. At low potential sweep rates (up to $10 \mathrm{mV} \mathrm{s}^{-1}$ ), two redox peak couples are seen, the first broad and the second well defined; the first peak is suppressed at higher potential sweep rates.

The dependence of peak current on $v^{1 / 2}$ is linear at all CuHCF films studied (Fig. 4b) and the ratio between oxidation and reduction currents is close to 1 (Table 1). Both types of electrochemically deposited film show quite similar peak currents and slopes, while at chemically deposited $\mathrm{CuHCF}$, the peak current is several times higher due to the thicker film. However, the peak potential dependence on $\lg v$ is not linear on any of the $\mathrm{CuHCF}$ films studied. This could be related to a different charge transfer mechanism to the film, since charge propagation is limited to counter ion transport $[6,39]$. Also, $\mathrm{CuHCF}$ may have a different structure from $\mathrm{Co}-$ HCF films. There is evidence for this from previous work: Chen and Chan used the electrochemical quartz crystal microbalance to examine the oxidation state of $\mathrm{Cu}$ and $\mathrm{Fe}$ in $\mathrm{CuHCF}$ and, regarding copper, found that only $\mathrm{Cu}^{\text {II }}$ exists in the complex [39]. The same result was found analysing the $\mathrm{CuHCF}$ precipitate chemically [42] or by elemental analysis of CuHCF powder obtained chemically or by a coagulation procedure [43]. In the last case, it was found that $\mathrm{CuHCF}$ powder consists of a mixture of $\mathrm{K}_{1.1} \mathrm{Cu}_{1.15}\left[\mathrm{Fe}^{\mathrm{III}}(\mathrm{CN})_{6}\right]$ and $\mathrm{K}_{0.8} \mathrm{Cu}_{1.6}\left[\mathrm{Fe}^{\mathrm{II}}(\mathrm{CN})_{6}\right]$.

\section{Electrochemical impedance spectroscopy}

Further studies of the $\mathrm{CoHCF}$ and $\mathrm{CuHCF}$ films were carried out by electrochemical impedance spectroscopy (EIS). Spectra recorded at $0.0 \mathrm{~V}$ and $+0.55 \mathrm{~V}$ versus SCE at the various films show some differences between the different deposition methods (Figs.6-7). A potential of $0.0 \mathrm{~V}$ was chosen because hydrogen peroxide oxidation

Table 1 Slopes of the peak current, $j_{\mathrm{p}}$, versus square root of sweep rate, $v$, plots from $\mathrm{CV}$ s recorded in $0.1 \mathrm{M} \mathrm{KCl}$ solution at $\mathrm{CoHCF}$ and $\mathrm{CuHCF}$ films deposited in different ways

\begin{tabular}{|c|c|c|c|}
\hline \multirow[t]{2}{*}{$\begin{array}{l}\text { Hexacyano- } \\
\text { ferrate }\end{array}$} & \multirow[t]{2}{*}{$\begin{array}{l}\text { Film deposition } \\
\text { method }\end{array}$} & \multicolumn{2}{|c|}{$\begin{array}{l}\text { Slope of } j_{\mathrm{p}} \text { versus } v^{1 / 2} / \\
\mathrm{mA} \mathrm{cm} \mathrm{mV}^{-1 / 2} \mathrm{~s}^{1 / 2}\end{array}$} \\
\hline & & $\begin{array}{l}\text { Oxidation } \\
\text { peak }\end{array}$ & $\begin{array}{l}\text { Reduction } \\
\text { peak }\end{array}$ \\
\hline $\mathrm{CoHCF}$ & Chemical & 0.043 & -0.047 \\
\hline \multirow[t]{3}{*}{$\mathrm{CuHCF}$} & Chemical & 0.129 & -0.117 \\
\hline & Galvanostatic & 0.034 & -0.033 \\
\hline & Potential cycling & 0.024 & -0.028 \\
\hline
\end{tabular}

Note: quantity calculus has been used. 
(a)
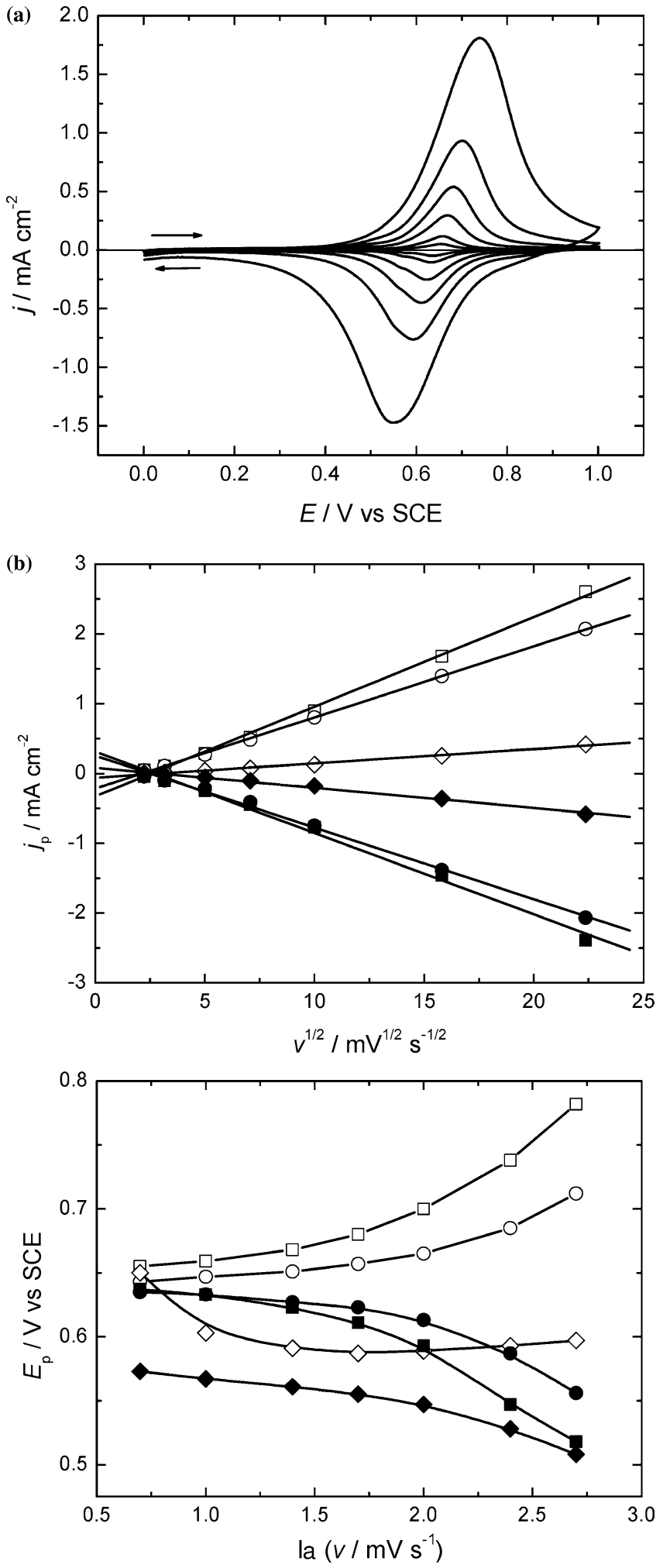

Fig. 5 Analysis of $\mathrm{CuHCF}$ films by cyclic voltammetry in $0.1 \mathrm{M}$ $\mathrm{KCl}$. a Cyclic voltammograms of $\mathrm{CuHCF}$, deposited chemically, at sweep rates, $v: 5 \mathrm{mV} \mathrm{s} \mathrm{s}^{-1}, 10 \mathrm{mV} \mathrm{s} \mathrm{s}^{-1}, 25 \mathrm{mV} \mathrm{s} \mathrm{s}^{-1}, 50 \mathrm{mV} \mathrm{s} \mathrm{s}^{-1}$, $100 \mathrm{mV} \mathrm{s}^{-1}, 250 \mathrm{mV} \mathrm{s}^{-1}$, and $500 \mathrm{mV} \mathrm{s}^{-1}$. b Analysis of cyclic voltammograms of $\mathrm{CuHCF}$ deposited chemically (open square, filled square), galvanosta-tically (open circle, filled circle), and by potential cycling (open diamond, filled diamond): dependence of peak current, $I_{\mathrm{p}}$, on $v^{1 / 2}$ and peak potential, $E_{\mathrm{p}}$, on $\lg v$ was performed at this potential (see below), and the second of $+0.55 \mathrm{~V}$ is where the film redox reaction takes place.

At $0.0 \mathrm{~V}$ (Fig. 6), both types of electrochemically deposited hexacyanoferrate films had similar impedance values (lower values in the case of galvanostatic deposition), while those from chemically deposited $\mathrm{CoHCF}$ and $\mathrm{CuHCF}$ films were higher, suggesting a more defectfree structure. These data are in agreement with cyclic voltammetry at these films. However, the results were different at $+0.55 \mathrm{~V}$ (Fig. 7): the lowest impedance values were obtained at the films deposited chemically. The impedance spectra show charge transfer control at high frequencies and diffusion control represented as a finite-length open-terminus Warburg element at low frequencies, as in [44]. The frequency range of each zone depended on the nature of the hexacyanoferrate and film deposition method. Data obtained are in good agreement with those reported in the literature [44, 45].

For spectra obtained at $0.0 \mathrm{~V}$ versus SCE, modelling was done using a $R_{\mathrm{ct}}-\mathrm{CPE}_{1}$ parallel combination equivalent circuit in series with the cell resistance $R_{\Omega}$, with $R_{\mathrm{ct}}$ representing the charge transfer resistance and $\mathrm{CPE}_{1}$ a non-ideal capacitor of exponent $n_{1}$ for fitting the spectra at $0.0 \mathrm{~V}$ (Fig. 6c), and the circuit was extended with a finite-length open terminus Warburg element in series at $+0.55 \mathrm{~V}$, as in [44], to represent cation diffusion in the metal hexacyanoferrate film (Fig 7c). The values of the fitted parameters are presented in Table 2 , where $C_{1}$ and $n_{1}$ are calculated for $\mathrm{CPE}_{1}$ and $C_{2}$ and $n_{2}$ for the openterminus Warburg element, $\mathrm{W}_{\mathrm{o}}$. They clearly show that both chemically deposited films have similar properties, but electrochemically deposited ones are slightly different, which suggests different structures obtained by chemical and electrochemical deposition.

Impedance studies at thin and thick CoHCF films at open circuit potential were reported in [3], where the thicker film showed a larger resistance and capacitance relaxation. However, impedance spectra depended not only on the thickness of the film, but also on the nature of counter cation. In other works and in order to calculate the diffusion coefficients of electrons and $\mathrm{K}^{+}$in the $\mathrm{CuHCF}$ composite (a mixture of $\mathrm{CuHCF}$ and graphite powder), impedance spectra were also recorded at $+0.64 \mathrm{~V},+0.69 \mathrm{~V}$, and $+0.74 \mathrm{~V}$ versus $\mathrm{Ag} / \mathrm{AgCl}$ (where the redox process of $\mathrm{CuHCF}$ takes place) in $0.1 \mathrm{M} \mathrm{KNO}_{3}$ [44]. Impedance spectra at those potentials had two regions, as found here by us: a semi-circle at high frequencies and finite-length open-terminus Warburg/capacitive region at low ones, and the frequency range depended on the nature of $\mathrm{CuHCF}[44,45]$.

\section{Response to hydrogen peroxide}

All films were tested for the determination of hydrogen peroxide in $0.1 \mathrm{M}$ phosphate buffer saline (PBS) solution, $\mathrm{pH} \mathrm{7,} \mathrm{at} 0.0 \mathrm{~V}$ versus $\mathrm{SCE}$ in order to find the best ones for application in oxidase enzyme biosensors. The 
films were first characterized by cyclic voltammetry in 0.1 M PBS electrolyte, $\mathrm{pH}$ 7. The CVs (not shown) are similar to those obtained in $\mathrm{KCl}$ solution, except that the
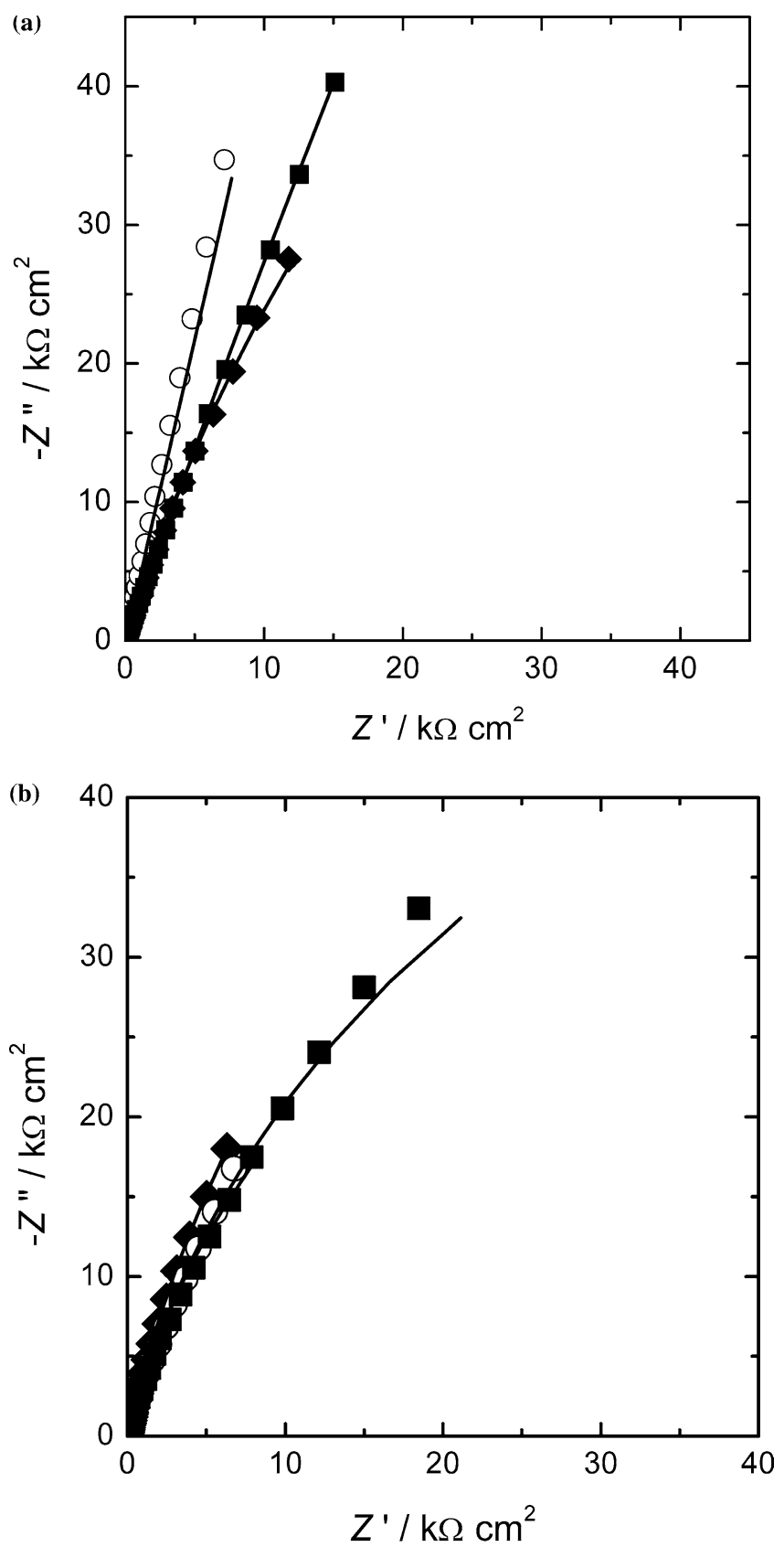

(c)

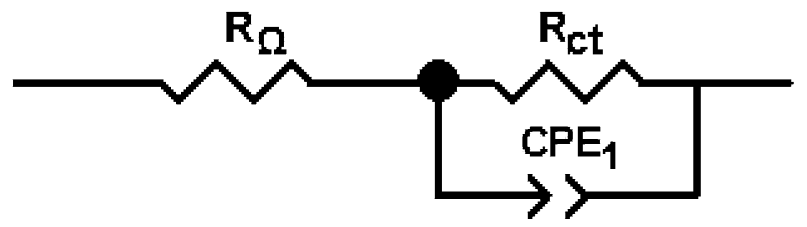

Fig. 6 Complex plane impedance spectra at $0.0 \mathrm{~V}$ of (a) $\mathrm{CoHCF}$ and (b) CuHCF deposited chemically (filled square), galvanostatically (open circle), and voltammetrically (filled diamond): symbols indicate the experimental data and lines the fitting using the equivalent circuit shown in (c). Supporting electrolyte $0.1 \mathrm{M} \mathrm{KCl}$ peaks are not so well defined and are shifted $\sim 0.1 \mathrm{~V}$ to more positive potentials. The $\mathrm{CoHCF}$ and $\mathrm{CuHCF}$ peaks decrease in height with the addition of $\mathrm{H}_{2} \mathrm{O}_{2}$ analyte, the extent depending on the way the film was deposited. Films of both hexacyanoferrates deposited at

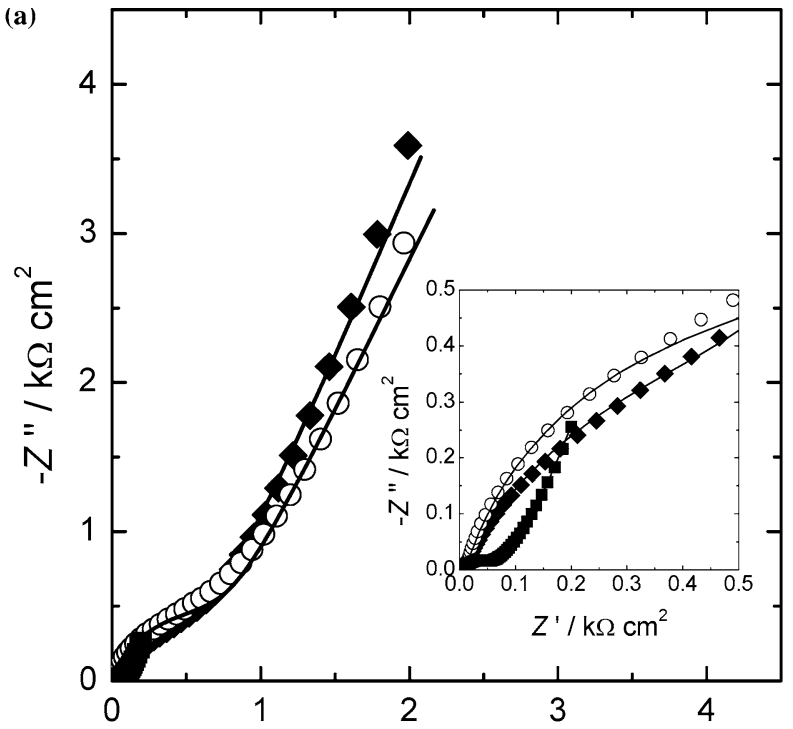

$Z^{\prime} / \mathrm{k} \Omega \mathrm{cm}^{2}$

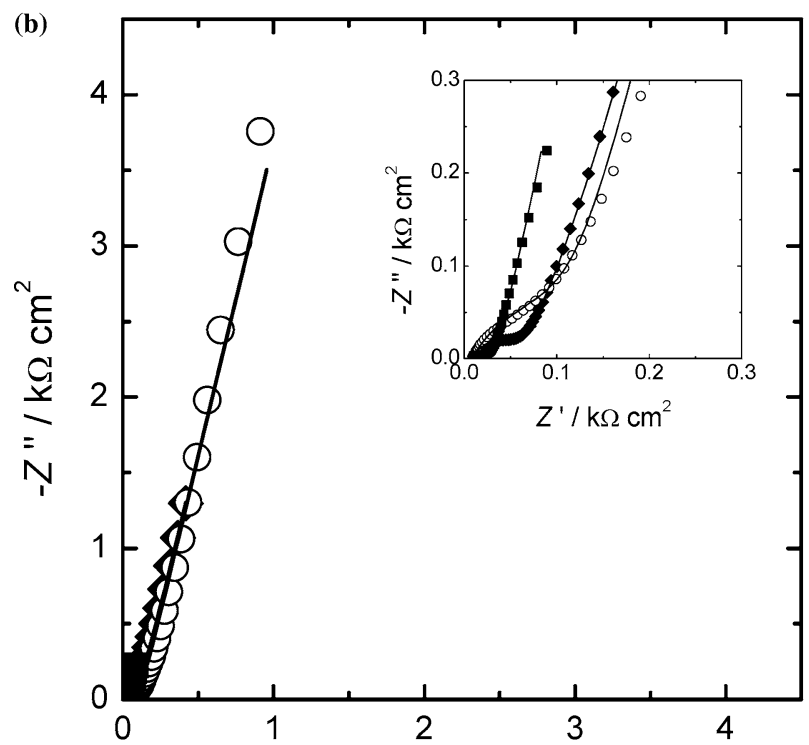

$Z^{\prime} / \mathrm{k} \Omega \mathrm{cm}^{2}$



Fig. 7 Complex plane impedance spectra at $0.55 \mathrm{~V}$ of (a) $\mathrm{CoHCF}$ and (b) $\mathrm{CuHCF}$ deposited chemically (filled square), galvanostatically (open circle), and voltammetrically (filled diamond): symbols indicate the experimental data and lines the fitting using the equivalent circuit shown in (c). Supporting electrolyte $0.1 \mathrm{M} \mathrm{KCl}$ 
Table 2 Calculated parameters from electrochemical impedance spectra (Figs. 6 and 7)

\begin{tabular}{|c|c|c|c|c|c|c|c|}
\hline $\begin{array}{l}E / \mathrm{V} \text { versus } \\
\text { SCE }\end{array}$ & Film & $R_{\Omega} / \mathrm{k} \Omega \mathrm{cm}^{-2}$ & $R_{\mathrm{ct}} / \mathrm{k} \Omega \mathrm{cm}^{2}$ & $C_{1} / \mu \mathrm{F} \mathrm{cm}^{-2} \mathrm{~s}^{n_{1}-1}$ & $n_{1}$ & $C_{2} / \mu \mathrm{F} \mathrm{cm}^{-2} \mathrm{~s}^{n_{2}-1}$ & $n_{2}$ \\
\hline \multirow[t]{5}{*}{0.0} & CoHCF (chemical) & 15.4 & 2165 & 33.0 & 0.79 & - & - \\
\hline & CoHCF (voltammetry) & 9.3 & 243 & 45.5 & 0.81 & - & - \\
\hline & CuHCF (chemical) & 7.9 & 118 & 32.1 & 0.84 & - & - \\
\hline & CuHCF (galvanostatic) & 7.8 & 95 & 73.2 & 0.85 & - & - \\
\hline & CuHCF (voltammetry) & 7.5 & 156 & 74.4 & 0.86 & - & - \\
\hline \multirow{4}{*}{0.55} & CoHCF (voltammetry) & 8.2 & 0.60 & 108 & 0.75 & 0.34 & 0.42 \\
\hline & CuHCF (chemical) & 2.5 & 0.003 & 12.6 & 0.92 & 6.71 & 0.48 \\
\hline & CuHCF (galvanostatic) & 8.8 & 0.11 & 91.4 & 0.80 & 0.04 & 0.43 \\
\hline & CuHCF (voltammetry) & 7.9 & 0.04 & 69.9 & 0.78 & 1.20 & 0.47 \\
\hline
\end{tabular}

Note: Quantity calculus has been used.

constant current exhibited the least decrease with increase in hydrogen peroxide concentration. The highest decrease of the peak current was at CuHCF deposited by chemical adsorption. The results led us to conclude that, at this $\mathrm{pH}$, electrocatalytic reduction of hydrogen peroxide occurs with the formation of hydroxyl ions:

$\mathrm{H}_{2} \mathrm{O}_{2}+2 \mathrm{e} \rightarrow 2 \mathrm{OH}^{-}$

The product of the electrocatalytic reduction causes a decrease in the height of the CoHCF and CuHCF peaks. A similar behaviour was found in a previous work with PB films [46].

The amperometric response to hydrogen peroxide at CoHCF deposited by potential cycling has been described previously [27]: the sensitivity was $17.2 \mathrm{nA}$ $\mu \mathrm{M}^{-1}$, with a very low detection limit of $0.27 \mu \mathrm{M}$, and the linear range was up to $5 \mu \mathrm{M}$.

The response to hydrogen peroxide at $\mathrm{CoHCF}$ and $\mathrm{CuHCF}$ films deposited in different ways is shown in Fig. 8, excluding $\mathrm{CoHCF}$ formed by potential cycling since the available concentration range is not easily seen on this scale. CoHCF deposited at constant current gave a poor response; chemical deposition led to a linear response over the whole concentration range studied, but sensitivity was not better than at the voltammetrically deposited film. Moreover, CoHCF films showed some lack of stability at neutral $\mathrm{pH}$, although it has been reported that $\mathrm{CoHCF}$, formed at $\mathrm{PB}$ electrodes by cycling the potential in $\mathrm{CoCl}_{2}$ solution, had a much better stability at neutral $\mathrm{pH}$ than the PB electrode [47]. However, it is possible that the authors obtained a mixed cation hexacyanoferrate, which are known to be more stable than those containing monocations [13, 48, 49].

CuHCF films deposited by potential cycling had a better sensitivity than $\mathrm{CoHCF}$ deposited chemically, but the linear range is not large enough for a biosensor. $\mathrm{CuHCF}$ deposited galvanostatically gave a poor response, similar to $\mathrm{CuHCF}$ deposited by potential cycling.

The best analytical properties from the films studied were from $\mathrm{CuHCF}$ deposited chemically with a sensi- tivity of $1.11 \mathrm{nA} \mu \mathrm{M}^{-1}$, a linear range from 10 to $600 \mu \mathrm{M}$, and detection limit $2.1 \mu \mathrm{M}$. Although it did not have as high a sensitivity and low limit of detection as the CoHCF studied in [27], it had a longer linear range and suitable sensitivity to be applied for electrochemical biosensors. Moreover, it was the most stable film of those described. A high stability at neutral $\mathrm{pH}(\mathrm{pH} 7.3)$ for the determination of $\mathrm{H}_{2} \mathrm{O}_{2}$ was also reported in [21], where $\mathrm{CuHCF}$ was deposited in 2 steps: galvanostatic pre-deposition of $\mathrm{Cu}$ and then cycling in hexacyanoferrate solution, operating at -0.2 or $0.0 \mathrm{~V} \mathrm{Ag} / \mathrm{AgCl}$.

All other films showed a lower sensitivity to hydrogen peroxide than $\mathrm{CuHCF}$ deposited chemically: $\mathrm{CoHCF}$ deposited by chemical immersion had a sensitivity $0.18 \mu \mathrm{M} \mathrm{nA}^{-1}$, linear range up to $1 \mathrm{mM}$, and detection limit $5.3 \mu \mathrm{M}$; CuHCF deposited by potential cycling had better sensitivity than CoHCF deposited by immersion, i.e. $0.86 \mathrm{nA} \mu \mathrm{M}^{-1}$, and similar detection limit $5.0 \mu \mathrm{M}$ but the linear range was much shorter, i.e. up to

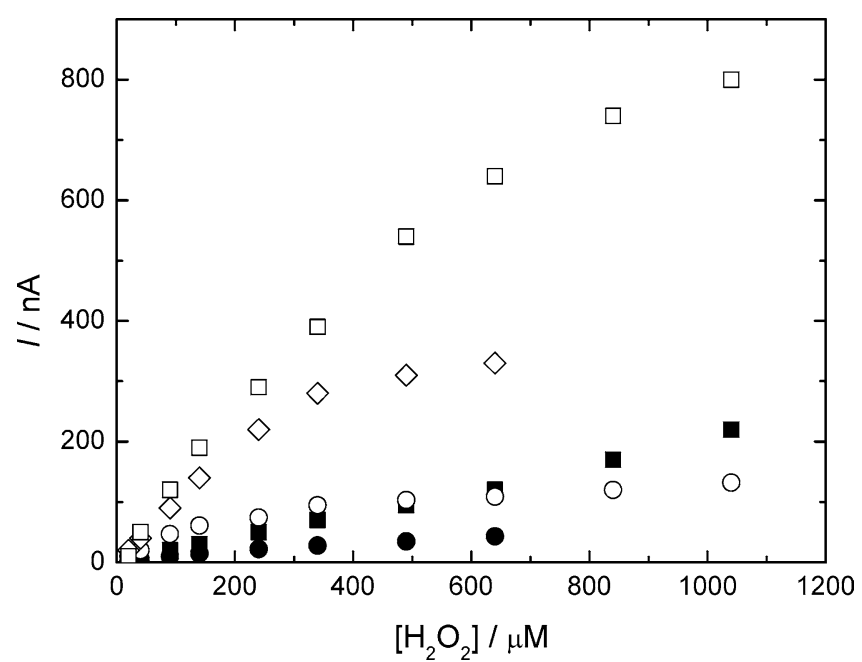

Fig. 8 Response to hydrogen peroxide at $+0.05 \mathrm{~V}$ versus SCE in $0.1 \mathrm{M}$ PBS at CoHCF (black symbols) and $\mathrm{CuHCF}$ (white symbols) deposited chemically (filled square, open square), galvanostatically (filled circle, open circle), and voltammetrically (open diamond) 
$350 \mu \mathrm{M}$. Galvanostatically deposited films had a poor sensitivity to $\mathrm{H}_{2} \mathrm{O}_{2}$.

\section{Conclusions}

Copper hexacyanoferrate and CuHCF, deposited at carbon film resistor electrodes by three different one-step processes, cycling of the electrode potential, by application of a constant current, or chemically, were characterized electrochemically using cyclic voltammetry and electrochemical impedance spectroscopy. Electrochemical redox reactions of the films were limited by diffusion of the counter cation. To evaluate the films for possible use as redox mediators for biosensors, they were applied to the determination of hydrogen peroxide in neutral media. Although CoHCF made by potential cycling is the most useful when a very low detection limit is necessary over a short timescale, chemically deposited $\mathrm{CuHCF}$ was found to be generally the most suitable as a mediator for biosensors.

Acknowledgements Financial support from Fundação para a Ciência e Tecnologia (FCT) Portugal, ICEMS (Research Unit 103), and European Project HPRN-CT-2002-00186 is gratefully acknowledged. R Pauliukaite thanks FCT for a postdoctoral fellowship (SFRH/BPD/14518/2003). Prof. H.-D. Liess is thanked for the gift of the electrical resistors.

\section{References}

1. Koncki R (2002) Crit Rev Anal Chem 32:79

2. Karyakin AA (2001) Electroanalysis 13:813

3. de Tacconi RN, Rajeshwar K, Lezna RO (2003) Chem Mater 15:3046

4. Horányi G, Inzelt G, Kulesza PJ (1990) Electrochim Acta $35: 811$

5. Kulesza PJ, Galus Z (1992) J Electroanal Chem 323:261

6. Kulesza PJ, Malik MA, Miecznikowski K, Wolkiewicz A, Zamponi S, Berrettoni M, Marassi R (1996) J Electrochem Soc 143:L10

7. Malik MA, Horányi G, Kulesza PJ, Inzelt G,Kertész V, Schmidt R, Czirok E (1998) J Electroanal Chem 452:57

8. Kulesza PJ, Malik MA, Berrettoni M, Giogetti M, Zamponi S, Schmidt R, Marassi R (1998) J Phys Chem B 102:1870

9. Kulesza PJ, Malik MA, Schmidt R, Smolinska A, Miecznikowski K, Zamponi S, Czerwinski A, Berrettoni M, Marassi R (2000) J Electroanal Chem 487:57

10. Malik MA, Miecznikowski K, Kulesza PJ (2000) Electrochim Acta $45: 3777$

11. Cataldi TRI, Centonze D, Guerrieri (1995) Anal Chem 67:101

12. Cataldi TRI, Guascito R, Salvi AM (1996) J Electroanal Chem 417:83
13. Cataldi TRI, De Benedetto GE, Bianchini A (1998) J Electroanal Chem 448:111

14. De Benedetto GE, Guascito MR, Ciriello R, Cataldi TRI (2000) Anal Chim Acta 410:143

15. Cataldi TRI, De Benedetto G, Bianchini A (1999) J Electroanal Chem 471:42

16. Karyakin AA, Gitelmacher OV, Karyakina EE (1994) Anal Lett 27:2861

17. Karyakin AA, Karyakina EE, Gorton L (1996) Talanta 43:1597

18. Chi QJ, Dong SJ (1995) Anal Chim Acta 310:429

19. Moscone D, D'Ottavi D, Compagnone D, Palleschi G, Amine A (2001) Anal Chem 73:2529

20. O'Halloran MP, Pravda M, Guilbault GG (2001) Talanta 55:605

21. Garjonyte R, Malinauskas A (1999) Sens Actuat B 56:93

22. Wang J, Zhang XJ, Prakash M (1999) Anal Chim Acta 395:11

23. Mattos IL, Gorton L, Laurell T, Malinauskas A, Karyakin AA (2000) Talanta 52:791

24. Lin MS, Wu YC, Jan BI (1999) Biotechnol Bioeng 62:56

25. Chen SM (2002) J Electroanal Chem 521:29

26. Eftekhari A (2003) Microchim Acta 141:15

27. Florescu M, Brett CMA (2004) Anal Lett 37:871

28. Cai CX, Xue KH, Zhou YM, Yang H (1997) Talanta 44:339

29. Milardović S, Kruhak I, Iveković D, Rumenjak V, Tkalčec M, Grabarić BS (1997) Anal Chim Acta 350:91

30. de Mattos IL, Gorton L (2001) Quim Nova 24:200

31. Chen S-M, Peng K-T (2003) J Electroanal Chem 547:179

32. Shankaran DR, Narayanan SS (2002) Sens Actuat B $86: 180$

33. Shankaran DR, Narayanan SS (1999) Fresen J Anal Chem 364:686

34. Brett CMA, Angnes L, Liess HD (2001) Electroanalysis 13:765

35. Filipe OMS, Brett CMA (2003) Talanta 61:643

36. Florescu M, Brett CMA (2005) Talanta 65:306

37. Filipe OMS, Brett CMA (2004) Electroanalysis 16:994

38. Joseph J, Gomathi H, Rao GP (1991) J Electroanal Chem 304:263

39. Chen SM, Chan CM (2003) J Electroanal Chem 543:161

40. Shankaran DR, Narayanan SS (1999) Fresen J Anal Chem 364:686

41. Lezna RO, Romangnoli R, de Tacconi NR, Rajeshwar K (2002) J Phys Chem B 106:3612

42. Antunes RMM, Sequeira CAC (2004) Ciênc Tecnol Mater (in Portuguese) 16:66

43. Makowski O, Stroka J, Kulesza PJ, Malik MA, Galus Z (2002) J Electroanal Chem 532:157

44. Kahlert H, Retter U, Lohse H, Siegler K, Scholz F (1998) J Phys Chem B 102:8757

45. Cardoso WS, Francisco MSP, Lucho AMS, Glushikem Y(2004) Solid State Ionics 167:165

46. Karyakin AA, Karyakina EE, Gorton L (1999) Electrochem Commun 1:78

47. Malinauskas A, Araminaitè R, Mickevičiūté G, Garjonytė R (2004) Mat Sci Eng C 24:513

48. Dostal A, Hermes M, Scholz F (1996) J Electroanal Chem 415:133

49. Mo JW, Ogorevc B, Zhang X, Pihlar B (2000) Electroanalysis $12: 48$ 